\title{
Erratum to: Participatory GIS for Urban Sustainability and Resilience: A Perspective of Social Learning and Ecology of Knowledge
}

Carolina Monteiro de Carvalho and Leandro Luiz Giatti

Erratum to:

Chapter "Participatory GIS for Urban Sustainability and Resilience: A Perspective of Social Learning and Ecology of Knowledge" in: U. M. Azeiteiro et al. (eds.), Lifelong Learning and Education in Healthy and Sustainable Cities, World Sustainability Series, https://doi.org/10.1007/978-3-319-69474-0_2

The original version of the book was inadvertently published without the acknowledgement text "This research is funded by FAPESP - Fundação de Amparo à Pesquisa do Estado de São Paulo (2015-21311-0)" which has been now included in Chapter 2 before "References". 